\title{
PREHOSPITAL STROKE DIAGNOSIS AND MANAGEMENT
}

\author{
Seher YAMAN*, Sakine BOYRAZ** \\ *112 Emergency Ambulance Services Ministry of Health, Aydın, TURKEY \\ **Adnan Menderes University, Faculty of Nursing, Department of Internal Medicine Nursing, Aydın, TURKEY
}

\begin{abstract}
INTRODUCTION: This study was carried out as a cross-sectional study for the purpose of evaluating 112 teams working in the Aydın dependent to the Ministry of Health, for the correct diagnosis of stroke cases and their interventions before the hospital.

METHODS: In the study, the incident reports, which were transferred to the hospital, were received from A2-type emergency health-stations located in the center of Aydın province. In the first phase of the study, 1453 incident reports were examined to determine the situation. In the light of the obtained data, the emergency medical team was trained for using "Cincinnati Prehospital Stroke Scale" in terms of stroke and diagnosis. In the second phase of the study 2029 incident reports (in total=3484 incidents) were examined to evaluate the efficiency of the training.) The data were analyzed through "Structured Questionnaire", "CPSS" and hospital emergency service records. Data analyses process was assessed by calculating sensitivity, specificity, and accuracy rates.

RESULTS: In the first phase, 91 cases and in the second phase 55 cases were pre-diagnosed with stroke and transferred to hospital emergency services. In the hospital emergency services, 63 cases were diagnosed with stroke in the first phase, and 63 cases were diagnosed with stroke in the second phase. The examination of diagnosis similarity between the two groups showed that in the first phase, $69.9 \%$ of the cases which were diagnosed with stroke in emergency services were consistent with the diagnosis of the 112 emergency medical team. The findings showed that in the second phase, $\% 38,1$ of the cases which were diagnosed with stroke in emergency services was consistent with the diagnosis of the 112 emergency medical team..Furthermore, in the second phase, it was determined that among the 55 incidents that were prediagnosed with stroke by 112 emergency medical teams, only $30(\% 54,5)$ of them were pre-diagnosed with CPSS. The results demonstrated that the CPSS sensitivity to true stroke pre-diagnosis was \%47. On the other hand, the results revealed that the trainings have had a positive impact on respiration support, circulation support and medical support interventions provided to stroke pre-diagnosed cases.

DISCUSSION and CONCLUSION: The research study revealed that 122 emergency medical teams have deficiencies in terms of true diagnosis of stroke cases in the pre-hospital phase, and therefore training support should be maintained.

Keywords: Stroke, Cincinnati prehospital stroke scale, 112 emergency service, stroke diagnosis.
\end{abstract}

\section{HASTANE ÖNCESI İNME TANILAMA VE YÖNETIMI}

\section{ÖZET}

GİRIȘ ve AMAÇ: Bu araștırma Sağlık Bakanlığı'na bağlı "Aydın 112 İl Ambulans Servisi"nde görev yapan 112 acil sağllk ekibinin, inme vakalarını doğru tanılama oranlarının ve inme vakalarına müdahalelerin değerlendirilmesi amacıyla kesitsel ve metodolojik bir çalıșma olarak yapılmıştır.

YÖNTEM ve GEREÇLER: Araştırmada, Aydın merkezde bulunan A2 tipi acil sağlık istasyonlarına ait, hastaneye nakil edilen vaka kayıtları alınmıștır. Araştırma iki aşamada gerçekleştirilmiştir. Birinci aşamada; durumu tespit etmek amacıyla 1453 vaka kaydı incelenmiștir. Elde edilen veriler dikkate alınarak 112 acil sağlık ekini inme ve tanılamada "Cincinati Hastane Öncesi İnme Skalası (CPSS)" kullanımı konusunda eğitilmiştir. İkinci aşamada; eğitimin etkinliğini değerlendirmek amacıyla 2029 vaka kaydı (toplam=3482 vaka) incelenmiștir. Veriler, "Yapılandırılmış Soru Formu”, "CPSS” ve hastane acil servis kayıtları incelenerek elde edilmiştir. Veri analizleri duyarlılık, özgüllük ve doğruluk oranı hesaplanarak değerlendirilmiştir.

\footnotetext{
Corresponding author: Sakine Boyraz, Prof. Adnan Menderes University, Faculty of Nursing, Department of Internal Medicine Nursing, Aydın, TURKEY. Telephone: +9002562138866/133_ E-mail: sakinememis@gmail.com Received: $20.11 .2018 \quad$ Accepted: 03.01.2019

This article should be cited as following: Yaman S, Boyraz S. Prehospital stroke diagnosis and management. Turkish Journal of Cerebrovascular Diseases 2019; 25 (1): 11-18. doi: 10.5505/tbdhd.2019.24892
} 
BULGULAR: 112 acil sağlık ekibi tarafından; birinci aşamada 91 vakaya, ikinci aşamada ise 55 vakaya inme ön tanısı konularak hastane acil servislerine nakledilmiș. Hastane acil servislerinde ise birinci aşamada 63 ve ikinci așamada da 63 vakaya inme tanısı konulmuştur. Bu iki grup arasında tanı benzerliği incelendiğinde; hastane acil servisinde inme tanısı konulmuş vakaların, birinci aşamada \%69,9'unun, ikinci aşamada ise \%38,1'inin inme tanısının 112 acil sağlık ekibi ile uyumlu olduğu belirlenmiștir. Ayrıca, ikinci așamada 112 acil sağlık ekipleri inme ön tanısı koydukları 55 vakanın sadece 30 'unda $(\% 54,5)$ CPSS kullandıkları tespit edilmiștir. CPSS inme ön tanısını doğru tespit etme duyarlılığının \%47 olduğu belirlenmiştir. Diğer yandan, İnme ön tanılı vakalara yapılan solunum desteği, dolaşım desteği ve medikal destek girişimlerinin eğitim sonrası olumlu yönde etkilendiği görülmüștür.

TARTIŞMA ve SONUÇ: Hastane öncesi dönemde 112 acil sağlık ekiplerinin inme vakalarını doğru tanılamada eksikliklerinin olduğu ortaya ve eğitim desteğinin sürdürülmesi gerektiği belirlenmiştir.

Anahtar Sözcükler: İnme, Cincinnati hastane öncesi inme skalası, 112 acil servis, inme tanılama.

\section{INTRODUCTION}

The stroke is a preventable, treatable health problem having a significant social impact throughout the world. The stoke as second cause of death in the world is the leading cause of disability for adults (1-5).

The most important stage regarding correct definition and early intervention to the stroke is the pre-hospital stage. The pre-hospital stage covers a period in which the stroke symptoms and findings are noticed by the individual or the witness, it is decided to seek medical care and transfer to the hospital $(6,7)$.The pre-hospital delay is also experienced at the stage of seeking medical care and transporting the patient. A study conducted in China calls attention to the fact that ambulance paramedics are incapable of diagnosing $1 / 3$ of stroke cases and to the imperfections regarding this field (8).

The efficacy of intravenous thrombolytic therapy with recombinant tissue plasminogen activator (rt-PA) was proven in patients with acute ischemic stroke in the first 3 hours. Following the European Cooperative Acute Stroke Study (ECASS3) concluded in 2008, the onset of treatment was extended to 4.5 hours (9-13). The transportation of stroke cases in 4.5 hours to a center having possibilities for a thrombolytic therapy is of vital importance (14).Despite comprehensive stroke centers providing high quality stroke treatment in our country, the adequate number is not reached yet. For this reason, the use of rt-PA for stroke patients is predicted to be increased in order to determine the reasons behind why do individuals apply to the hospitals late, and to take necessary measures (6, $15,16)$.

Based on the fact that patient outcomes will be improved with organized care in stroke cases, many organizations try to standardize stroke treatment and care. The algorithms for interventions and diagnosis of stroke were specified in our country according to "Adult Application and Infant Application Manual" (17) and Stroke Clinic Protocol (7) published by Ministry of Health. According to that manual, the use of Cincinati Prehospital Stroke Scale (CPSS) was recommended for pre-diagnosis of stroke by ambulance paramedics. However, no study was found assessing the outcomes of CPSS that was recommended to be used in the manual for prediagnosis of stroke. Besides, the studies in our country examining the role of 112 emergency service on pre-hospital delay period in the stroke cases are insufficient.

As result of this study, it is aimed to contribute to the acute stroke data by evaluating correct diagnosis of stroke cases by 112 ambulance paramedics, which stands as one of the most significant reasons for pre-hospital delay, and increasing correct intervention in the management of stroke cases.

\section{MATERIAL AND METHODS}

Aim of the study; this study was conducted to evaluate the correct diagnosis of and interventions to stroke cases by the ambulance paramedics working in Aydin 112 Provincial Ambulance Service, that is affiliated to the Ministry of Health.

Type of study; the study was conducted as cross-sectional and methodological.

Place of study; Three A2 type (where one paramedic, one assistant health-care personnel are present in the ambulance) Emergency Health Stations located in central Aydin affiliated to Aydin 112 Provincial Ambulance Service. The records of the patients who were transported to the hospital following an on-site intervention were assessed. However the records of A1 type (where one physician, one assistant personnel are present in 
the ambulance) stations and cases not transported to the hospital (inter-hospital transportation, onsite intervention, transportation to the house, leaving on the place of death, rejection of transportation, cancellation of duty, false alarm, transportation with another vehicle, waiting on the scene, transportation for medical inspection) were not included in the study.

Study population/sampling; the sampling was not chosen, and the records of all cases transported to the hospital were examined in two stages. Stages of the study:

1) First stage; the ambulance case forms $(\mathrm{N}=1453$ case records) of three months (December/January/February, 2017) were examined to determine the situation.

2) The ambulance staffs were trained in stroke diagnosis and management.

3) Second stage; the ambulance case forms $(\mathrm{N}=2029$ case records) of three months (June/July/August, 2017) were examined to determine the effect of training. In total, 3482 case records were examined in the study.

Data collection tool; the research data were obtained by a "Structured Questionnaire" prepared by the researcher and "CPSS".

Structured Questionnaire; was prepared relying on the literature information (18), "Ministry of Health, Aydin 112 Provincial Ambulance Service Registration Form" and "Adult Application and Infant Application Manual" published by Ministry of Health. The following items were recorded into this form;

- the stroke pre-diagnosis and other diagnosis by 112 ambulance paramedics;

- pre-hospital interventions to the cases prediagnosed with stroke;

- the diagnoses made to the same cases in the emergency services (obtained from hospital records).

CPSS; This scale developed by Kothari et al. (18) is comprised of three chapters assessing "facial droop", "arm drift" and "speech difficulty". In case any of these three signs is abnormal, the stroke possibility is appreciated as $72 \%$. The application of the scale takes one to two minutes and its evaluation is marked as "normal" or "abnormal". As CPSS is not included in Aydin 112 Provincial Ambulance Service Registration Form; it was made in a short and understandable seal, and added to the case forms of emergency health stations falling within the scope of the research, in the second quarter.
Data collection; Research data were obtained in two stages. Whereas;

In the first stage, quarterly case records were examined retrospectively. For this reason; the records from Ministry of Health, Aydin 112 Provincial Ambulance Service Registration Form were benefited and "Structured Questionnaire" was filled out.

Thereafter, the Paramedics and Emergency Medical Technicians (total number $=29$ ) who are in charge of three emergency health stations that were included in the scope of the research were trained with update training on pre-hospital stroke diagnosis and management, based on the stroke flow diagram included in "Pre-hospital Emergency Medical Care Adult and Infant Application Manual" of the Ministry of Health. For ensuring participation to the training, the support of Aydin Provincial Health Directorate, Department of Emergency Health Services was received.

The training was held by the researcher in the stations and in small groups (approx. four participants) for 40-45 minutes by the aid of computer (standard training material) and through interactive participation. The training was completed in one week and in the times the personnel were off. The content of the standard training material included subjects such as the definition of stroke, the stroke alarm symptoms, other diseases pretending stroke, the importance of correct diagnosis of stroke cases in pre-hospital period and the intervention to the stroke cases by use of CPSS. As CPSS is not included in Aydin 112 Provincial Ambulance Service Registration Form; it was made in a short and understandable seal, and included in the case forms of emergency health stations under the scope of the research, by approval of Aydin Provincial Health Directorate, Department of Emergency Health Services.

In the second stage following the training, quarterly case records and hospital records were reviewed and the data collection was completed.

Data assessment; the data analyzes were performed in "Statistical Package for Social Sciences (SPSS) for Windows-18“.For interpretation of findings, the frequency tables and descriptive statistics were used.Sensitivity, specificity, accuracy and positive predictive values were calculated in the assessment.

Ethical aspect of the study; necessary official permission was received for ethical compliance of the study from Adnan Menderes University,

Turkish Journal of Cerebrovascular Diseases 2019; 25 (1): 11-18 
Faculty of Medicine, Non-Interventional Clinical Research Ethics Committee (Protocol No: 2016/783); and for data collection from Aydin Health Directorate (dated 02.03.2016 numbered 2769).

\section{RESULTS}

In this study conducted to evaluate the rate of ambulance paramedics who are in charge in Aydin 112 Provincial Ambulance Service affiliated to the Ministry of Health to diagnose stroke cases accurately and their interventions to the stroke cases, the records from total 3482 cases were examined in the data collected in two periods.

Based on the most frequent pre-diagnoses made by 112 ambulance paramedics, it was observed that the most frequently made prediagnosis is "respiratory system" diseases in the first stage, and "trauma" in the second stage. Considering them in terms of stroke pre-diagnosis; 112 ambulance paramedics made intervention to 91 out of 1453 cases in first stage and 55 out of 2029 cases in second stage by making stroke prediagnosis (Table I). Considering the diagnoses made in the emergency services of the hospitals for these cases; it was observed that 63 out of 1453 cases $(4,3 \%)$ in first stage and 63 out of 2029 cases $(3,1)$ in second stage were diagnosed with stroke.

Table I. Distribution of pre-diagnoses made by 112 ambulance paramedics $(\mathrm{N}=3482)$.

\begin{tabular}{lcccc}
\hline Pre-diagnoses by 112 & \multicolumn{2}{c}{ First stage } & \multicolumn{2}{c}{ Second stage } \\
ambulance paramedics & \multicolumn{2}{c}{$(\mathrm{n}=1453)$} & \multicolumn{2}{c}{$(\mathrm{n}=2029)$} \\
& $(\mathrm{n})$ & $(\%)$ & $(\mathrm{n})$ & $(\%)$ \\
\hline Respiratory system diseases & 246 & 16,9 & 188 & 9,3 \\
General symptoms & 217 & 14.9 & 347 & 17.1 \\
Trauma & 196 & 13.5 & 416 & 20.5 \\
Cerebral symptoms & 155 & 10.7 & 195 & 9.6 \\
GIS Symptoms* & 141 & 9.7 & 163 & 8.0 \\
Hypo/Hypertension & 130 & 8.9 & 138 & 6.8 \\
Stroke & $\mathbf{9 1}$ & $\mathbf{6 . 3}$ & $\mathbf{5 5}$ & $\mathbf{2 . 7}$ \\
Anxiety & 69 & 4.7 & 186 & 9.2 \\
Other conditions & 59 & 4.1 & 152 & 7.5 \\
Angina pectoris & 59 & 4.1 & 92 & 4.5 \\
Diabetes & 48 & 3.3 & 44 & 2.2 \\
Epilepsy & 42 & 3.0 & 53 & 2.6 \\
\hline *GIS; Gastrointestinal system & & & &
\end{tabular}

${ }^{*}$ GIS; Gastrointestinal system

The primary aim of 112 emergency health services in stroke cases is fast assessment, early stabilization, neurological assessment and fast transportation to an hospital eligible for stroke intervention. One of the reasons for pre-hospital delay in cases with acute stroke is the transportation process of the patients. Examining the time use by 112 ambulance paramedics intervening in the cases with stroke pre-diagnosis; it was found that in both stages they arrived at the scene generally between 1-10 minutes (93,4\%$80 \%$; they spent 1-15 minutes at the scene $(90,1 \%-94,5 \%)$ and they arrived at the hospital in $1-10$ minutes $(94,5 \%-81,8 \%)$. It was further found that the cases with stroke pre-diagnosis were directed in first stage to Aydin State Hospital (52, $\% 8$ ) and in second stage to Adnan Menderes University Application and Research Hospital $(36,3 \%)$.

Comparing patients diagnosed with stroke in emergency services of the hospitals to those referred to the hospitals with a stroke prediagnosis by 112 ambulance paramedics; it was found that $69,9 \%$ in first stage and $38,1 \%$ in second stage of cases diagnosed with stroke in emergency services of the hospitals were referred by 112 ambulance paramedics with a stroke prediagnosis (Table II).

Table II. Comparison of the patients diagnosed with stroke in the emergency services of the hospitals with the condition transported to hospital following a stroke pre-diagnosis made by 112 ambulance paramedics.

\begin{tabular}{lccccc}
\hline & \multicolumn{3}{c}{$\begin{array}{c}\text { Those diagnosed with stroke in the emergency } \\
\text { services of the hospitals }\end{array}$} \\
\cline { 2 - 6 } & & \multicolumn{5}{c}{ First stage } & \multicolumn{3}{c}{$\begin{array}{c}\text { Second stage } \\
\text { Stroke pre- }\end{array}$} \\
$\begin{array}{l}\text { diagnosis by } \\
112 \text { ambulance }\end{array}$ & Diagnosed & 44 & 69,9 & 24 & 38,1 \\
paramedics & Not diagnosed & 19 & 30.1 & 39 & 61.9 \\
Total & & 63 & 100 & 63 & 100 \\
\hline
\end{tabular}

As shown in Table II; when examined the cases not pre-diagnosed with stroke by 112 ambulance paramedics $(\mathrm{n}=19)$, despite a stroke diagnosis made in the emergency service of the hospital in the first stage; the hyper/hypotension $(n=5)$, general symptoms $(n=4)$, Gastrointestinal System symptoms and cerebral symptoms (vertigo, headache, etc.) $(n=3)$ were diagnosed. In the second stage, when examined the cases not pre-diagnosed with stroke by 112 ambulance paramedics $(n=39)$, despite a stroke diagnosis made in the emergency service of the hospital; the general symptoms $(\mathrm{n}=13)$, hyper/hypotension $(n=9)$ and cerebral symptoms (vertigo, headache, etc.) $(n=5)$ were diagnosed.

In this study, it was observed for the cases 
pre-diagnosed with stroke by 112 ambulance paramedics that the positive predictive value was $48 \%$ and sensitivity was $64 \%$, in the first stage, while positive predictive value was $43 \%$ and sensitivity was $38 \%$ in the second stage. Based on this result, it is seen that 112 ambulance paramedics made an accurate stroke diagnosis in the rate of two third in the first stage, however this rate was decreased to one third in the second stage.

In our country, the use of CPSS is also recommended in the stroke intervention algorithm developed by Ministry of Health for 112 ambulance paramedics. Despite this, the ambulance registration form does not contain any section regarding CPSS. For this reason, the first stage of the study provides no finding regarding CPSS data. In the second stage, it was added to the ambulance registration form by the researcher. In the training held, information about the intended use of CPSS, the assessment method and its use for each case were provided. When assessed the use of CPSS in the cases pre-diagnosed with stroke by 112 ambulance paramedics in the second stage; it was found they used CPSS for $30(54,5 \%)$ of the cases pre-diagnosed with stroke $(n=55)$ (Table III).

Table III. Assessment CPSS use in the cases prediagnosed with stroke by 112 ambulance paramedics in the second stage.

\begin{tabular}{llcc}
\hline & & \multicolumn{3}{c}{ In the second stage } \\
& & & \multicolumn{3}{c}{$(\mathrm{n}=55)$} & \\
& & $(\mathrm{n})$ & $(\%)$ \\
\hline \multirow{2}{*}{ CPSS } & Used & 30 & $\mathbf{5 4 . 5}$ \\
& Not used & 25 & 45.5 \\
\hline
\end{tabular}

When examined how CPSS was interpreted in these cases; it was observed that a case of which CPSS was assessed as normal by 112 ambulance paramedics was diagnosed with stroke in the emergency service of the hospital (wrong positive), whereas on the other hand, 12 cases of which CPSS was assessed as abnormal were not diagnosed with stroke (wrong negative) (Table IV). Hence, it was determined that positive predictive value was $91 \%$, sensitivity was $47 \%$, specificity was $86 \%$ and accuracy rate was $56 \%$ for the use of CPSS in the cases pre-diagnosed with stroke using CPSS $(n=30)$.

It was observed there are cases $(n=12)$ assessed wrong negative (pre-diagnosed with stroke using CPSS, however not diagnosed with stroke in the emergency service) by 112 ambulance paramedics. It was determined that the pre-diagnoses made for these cases in the emergency services were syncope (one case), anxiety (two cases), trauma (two cases), angina pectoris (one case), general symptoms (one case), and five cases were not diagnosed.

It was further observed that the respiration support (oxygen administration etc.), circulatory support (use of solution etc.) and medical interventions (blood pressure measurement, monitorization etc.) applied by 112 ambulance paramedics to the cases pre-diagnosed with stroke positively increased in the second stage.

Table IV. Assessment CPSS use in the cases prediagnosed with stroke by 112 ambulance paramedics in the second stage.

\begin{tabular}{|c|c|c|c|c|}
\hline \multicolumn{5}{|c|}{$\begin{array}{c}\text { Results from the use of CPSS by } 112 \\
\text { Ambulance Paramedics }\end{array}$} \\
\hline & \multicolumn{2}{|c|}{ Normal } & \multicolumn{2}{|c|}{ Abnormal } \\
\hline & (n) & $(\%)$ & & $(\%)$ \\
\hline Diagnosed & 1 & 14,2 & 11 & 47,9 \\
\hline \multirow[t]{2}{*}{ Not diagnosed } & 6 & 85,8 & 12 & 52,1 \\
\hline & 7 & 100 & 23 & 100 \\
\hline
\end{tabular}

\section{DISCUSSION}

In this study the records of total 3482 cases were examined in the data collected in two stages. Based on the most frequent pre-diagnoses made by 112 ambulance paramedics, it was observed that the most frequently made pre-diagnosis is "respiratory system" diseases in the first stage, and "trauma" in the second stage. Considering them in terms of stroke pre-diagnosis; 112 ambulance paramedics made intervention to 91 cases in first stage and 55 cases in second stage by making stroke pre-diagnosis (Table I). Kidak et al. (19) informed in a study they evaluate the use of 112 ambulance services in Izmir, that the rate of neurological disease pre-diagnosis made by 112 ambulance paramedics in all cases $(\mathrm{N}=102$ 905) was 9,3\%.Oktay and Kayisoglu (20) reported in their study that the trauma was the leading diagnosis based on the evaluations they made successively for three years. Onge et at. (21) reported in their study examining the prediagnoses of 112 ambulance paramedics that the trauma cases were in the lead with a rate of $28,4 \%$. 
As fist stage cases were assessed in winter, the rate of respiratory system diseases (COPD and Asthma) were high as expected. However, the high number of trauma pre-diagnoses in the second stage are thought to be caused from traffic intensity in summer (on the routes to holiday territories) and the increased number of accidents.

When examined the diagnoses made in emergency services of the hospitals in terms of "stroke", this rate was reported as 4,3\% in the first stage ( $\mathrm{n}=63)$, while it was $3,1 \%$ in the second stage $(n=63)$ (Table II). Andjelik (22) determined in her study comparing the diagnoses made by ambulance paramedics to those made in the hospital ( $\mathrm{N}=2881$ cases) that the rate of stroke was $3,7 \%$.

One of the reasons for pre-hospital delay in cases with acute stroke is the transportation process of the patients. Smith et al. (23) found in a study they conducted that the time spent to travel to the scene for stroke cases was approximately 6,9 minutes, the time spent at the scene was 23 minutes and the time spent to travel to the hospital was 11 minutes. It is thought that in this study the time spent to travel to the scene, the time spent at the scene and the time spent to travel to the hospital are quite good in both stages. Properly located 112 ambulance paramedics in central Aydin and appropriate traffics conditions are though to be effective on this result.

$69,9 \%$ of the cases who were diagnosed with stroke in the emergency services of the hospital were referred by 112 ambulance paramedics with a stroke pre-diagnosis, whereas this rate was $38 \%$ in the second stage (Table II).Kothari et al. (18) reported in a study they conducted for the frequency and accuracy of pre-hospital acute stroke diagnoses that 96 of total 4413 cases were referred by ambulance paramedics with stroke pre-diagnosis, and based on the hospital records of 86 cases thereof, the stroke diagnosis for 63 patients (72\%) was confirmed in the emergency services. Brandler et al. (24) suggested in their study regarding pre-hospital stroke diagnosis that 453 cases were transported to the hospital by ambulance paramedics with stroke prediagnosis/suspicion, and 186 cases thereof were diagnosed with stroke in the emergency service. It was reported that 141 cases thereof $(75,8 \%)$ were also pre-diagnosed with stroke by ambulance paramedics.

In this study, it was observed for the cases pre-diagnosed with stroke by 112 ambulance paramedics that the positive predictive value was $48 \%$ and sensitivity was $64 \%$, in the first stage, while positive predictive value was $43 \%$ and sensitivity was $38 \%$ in the second stage. Based on this result, it is seen that 112 ambulance paramedics made an accurate stroke diagnosis in the rate of two third in the first stage, however this rate was decreased to one third in the second stage. Depending on this result, it is thought that other symptoms of stroke (hypoesthesia, visual field loss, cognitive disorders etc.) were ignored as result of directing the use of CPSS to measure three major findings (droop on one side of the face, weakness on the arm at the affected side and speech disorder).Smith et al. (23) reported in a similar study they conducted that positive predictive value of paramedic stroke diagnoses was $77 \%$ and the sensitivity thereof was $61 \%$. Wojner-Alexandrov et al. (25) found in a twostage study they conducted for paramedical diagnoses that the positive predictive value thereof was $61 \%$ and the diagnostic sensitivity was $61 \%$ in pre-intervention period, and respectively $65 \%$ and $79 \%$ in active intervention period.

Early diagnosis and correct intervention to the stroke in pre-hospital period are significant factors to decrease mortality rate and to increase life quality. The use of evidence-based diagnostic tools for stroke such as CPSS is recommended in many studies to diagnose stroke within prehospital period. In the second stage of this study, CPSS was used for more than half of cases prediagnosed with stroke (Table III). It was determined that positive predictive value was $91 \%$, sensitivity was $47 \%$, specificity was $86 \%$ and accuracy rate was $56 \%$ for the use of CPSS in the cases pre-diagnosed with stroke using CPSS $(n=30) . W o j n e r$ et al. (31) stated as result of the study that CPSS sensitivity was $66 \%$, specificity was $98 \%$ and accuracy rate was $72 \%$ in the stroke diagnoses made by paramedics. Bray et al. (32) defined in a similar study that the sensitivity of CPSS use in diagnosing stroke cases was $87 \%$. Kessler et al. (29) found that the use of CPSS was 95\% sensitive and 65\% specific for confirming stroke diagnoses. Fassbender et al. (33) determined in their study involving 843 stroke cases that the stroke diagnostic specificity of CPSS was $66 \%$, while the sensitivity thereof was $90 \%$. Zohrevandi et al. (30) found in their study that the CPSS stroke scale revealed $93,2 \%$ sensitivity and $51,8 \%$ specificity in pre-hospital stroke diagnosis. 
Katz et al. (28) stated that CPSS stroke scale is $92 \%$ sensitive in pre-hospital stroke diagnosis.

Although many studies showed that CPSS is quite sensitive to diagnose stroke, some studies reported low sensitivity (as in our study). The stroke alarm symptoms are not same for all patients. The alarm symptoms differ according to the localization of the stroke, the size of the affected vessel and the development speed of the stroke. On the other hand, the severity of neurological loss depends on the collateral blood flow, individual differences in the vascular anatomy, the blood pressure and the exact localization of the occlusion. The clinic of stroke cases caused from small artery atherosclerosis is usually characterized by cognitive disorders, while lacunar infarcts cause more clinical stereotypic clinical symptoms (34). This result shows the necessity of repeating the training for 112 ambulance paramedics regarding the risk factors of stroke, the alarm symptoms of stroke and the use of CPSS. Besides, it is thought that 112 ambulance paramedics are incapable of keeping medical records. The study of Cakir et al. (35) determined that 112 forms were not properly and sufficiently filled out, and hence supports our study.

It was found in this study that the cases which were diagnosed with stroke in emergency service of the hospital although they were not prediagnosed with stroke by ambulance paramedics showed in the first stage $(n=19)$ hypo/hypertension $(\mathrm{n}=5)$, general symptoms $(n=4)$, cerebral symptoms $(n=3)$ etc.; and in the second stage $(n=39)$ general symptoms $(n=13)$, hypo/hypertension $(\mathrm{n}=9)$, cerebral symptoms $(n=5)$ etc. Smith et al. (23) stated in their study that, out of cases found as wrong positive $(n=5), 6$ cases were metabolic diseases showing neurological symptoms, 3 cases were new metabolic situations (urosepsis, fever of which cause is unknown, etc.) having stroke history and 3 cases were the cases having focal neurological findings. Wojner-Alexandrov et al. (25) asserted in their study that the diagnoses made wrongly were seizure disorders, changing mental conditions, headache and syncope. Bray et al. (32) set forth in their study that 8 of 207 stroke cases were confused by 112 ambulance paramedics with confusion, vertigo, nausea, falling, migraine and urinary tract infections. In the literature, clinical conditions such as hypoglycemia, syncope, anxiety, seizure, hypertensive encephalopathy and migraine attacks are reported to mimic stroke (3, $36,37,38)$.Therefore, 112 ambulance paramedics could not distinguish the conditions mimicking stroke using CPSS assessment.

As a result of this study conducted to evaluate correct diagnosis of (by comparing with hospital emergency service) and intervention to stroke cases by paramedics employed in Aydin 112 Provincial Ambulance Service (total 3482 cases); it was observed that 112 ambulance paramedics pre-diagnosed 91 cases in the first stage and 55 cases in the second stage of the study with stroke (after training 112 ambulance paramedics about stroke and use of CPSS). However, it was found that 63 cases in the first stage and 63 cases in the second stage were diagnosed with stroke in the emergency services of the hospitals.

It was determined that the stroke diagnosis made by 112 ambulance paramedics in the first stage was consistent in three fourth $(n=44)$ of the cases diagnosed with stroke in the emergency service, whereas this rate was one third $(n=24)$ in the second stage. The sensitivity of 112 ambulance paramedics to correctly diagnose stroke cases was found as $64 \%$ in the first stage and as $38 \%$ in the second stage.

The sensitivity of CPSS used by 112 ambulance paramedics to correctly recognize stroke pre-diagnosis was determined to be $47 \%$.It was determined there are cases $(n=12)$ prediagnosed with stroke by 112 ambulance paramedics using CPSS, however not diagnosed with stroke in the emergency service. It is thought that 112 ambulance paramedics cannot distinguish the conditions mimicking stroke using CPSS assessment.

Considering these results, it is recommended to ensure continuity of the trainings provided to 112 ambulance paramedics on the risk factors of stroke, the alarm symptoms of stroke and the use of CPSS.

\section{REFERENCES}

1. Hankey GJ. Preventable stroke and stroke prevention. J Thromb Haemost 2005; 3: 1638-45.

2. Durna Z, Tülek Z. İnme bakım. İn: Durna Z ed. Kronik Hastalıklar ve Bakım. 1.baskı, Nobel Tıp Kitapevi, İstanbul, 2012; 239-261

3. Jauch EC, Saver JL, Adams HP Jr, et al. Guidelines fort the early management of patients with acute ischemic stroke: A guideline for healthcare professionals from the American Heart Assocation/ American Stroke Association, Stroke 2013;44:870-947.

4. Hölscher T, Dunforr JV, Schlachetzki F, et al. Prehospital stroke diagnosis and treatment in ambulances and

Turkish Journal of Cerebrovascular Diseases 2019; 25 (1): 11-18 
helicopters a concept paper. Amerikan Journal of Emergency Medicine 2013; 31: 743-747.

5. Benjamin EJ, Blaha MJ, Chiuve SE, et al. Heart disease and stroke statistics-2017 update: A Report from the American Heart Association. Circulation 2017;135:000-000.

6. Tunç C. İnmeli Bireylerin Hastaneye Başvurma Sürelerini Etkileyen Etmenlerin İncelenmesi. Yüksek Lisans Tezi. Dokuz Eylül Üniversitesi Sağlık Bilimleri Enstitüsü, İzmir, 2011.

7. İnme Klinik Protokolü, Sağlık Bakanlığı Sağlık Araștırmaları Genel Müdürlüğü, 2018. http://www.hta.gov.tr/pdf/InmeProtokolu/files/basichtml/page6.html

8. Jiang $\mathrm{B}, \mathrm{Ru} \mathrm{X}$, Sun $\mathrm{H}$, et al. Prehospital delay and its associated factors in first-ever stroke registered in communities from three cities in Chine, Sci Rep. 2016; 6: 29795.

9. Ringleb PA, Bausser M, Ford G, et al. İskemik inme ve geçici iskemik atağa yaklașım rehberi. 2008. http://www.congrexswitzerland.com/fileadmin/files/2013/esostroke/pdf/ESO 08_Guidelines_Turkish.pdf

10. Tanrıverdi Z, Örken DN, Aksoy S, ve ark. Akut iskemik inmede intravenöz trombolitik tedavi: Şişli Etfal Eğitim ve Araştırma Hastanesi nöroloji kliniği deneyimi. Ş.E.E.A.H. Tıp Bülteni 2012;46(4):165-169.

11. Kutluk K. İnme Tanı ve Tedavi. O’Tıp Kitapevi, 1. Baskı, İzmir, 2016.

12. Akut İskemik İnmede İntravenöz Doku Plazminojen Aktivatörü (tPA) Kullanım Cep Kitapçı̆̆ı 2017, Türk Nöroloji Derneği'nin yayını, Galenos Yayınevi Tic. Ltd. Şti. http://www.noroloji.org.tr

13. Powers WJ, Rabinstein AA, Ackerson T, et al. 2018 guidelines for the early management of patients with acute ischemic stroke. A Guideline for Healthcare Professionals From the American Heart Association/American Stroke Association Stroke. 2018;49:eXXX- eXXX. doi: 10.1161/STR.0000000000000158.

14. Middleton S, Grimley R, Alexandrov AE. Triage, treatment and transfer. Evidence based clinical practice recommendations and models of nursing care for the first 72 hours of admission to hospital for acute stroke. Stroke 2015;46(2):e18-25.

15. Livesay SL. Clinical review and implications of the guideline for the early management of patients with acute ischemic stroke. AACN Adv Crit Care. 2014;25(2):130-41.

16. Oruç $\mathrm{S}$, Demirbas $\mathrm{H}$, Yaman $\mathrm{M}$, ve ark. Akut iskemik inmeli olgularda Kocatepe Üniversitesi nöroloji kliniğinin intravenöz trombolitik tedavi deneyimleri. Türk Beyin Damar Hastalıkları Dergisi, 2015; 21(3):189-193.

17. Sağlık Bakanlığı Sağlık Hizmetleri Genel Müdürlüğü Klinik Kalite Daire Başkanlığı. Klinik kalite rehberi: İnme, 2015. 11/5/2000 tarihli ve 24046 sayll Resmî Gazete'de yayımlanan Acil Sağlık Hizmetleri Yönetmeliği (Madde 28) tarihli 26463 sayll Sağlı 15/3/2007 Acil Hizmetleri Yönetmeliğinde Değişiklik Yapılmasına Dair Yönetmelik (Madde 10) (http://www.resmigazete.gov.tr)

18. Kothari R, Hall K, Brott $\mathrm{T}$, et al. Early stroke recognition: Developing an out-of-hospital NIH stroke scale. Acad Emerg Med. 1997 Oct;4(10):986-90.
19. Kıdak L, Keskinoğlu P, Sofuoğlu T, ve ark. İzmir ilinde 112 acil ambulans hizmetlerinin kullanımının değerlendirilmesi. Genel Tıp Dergisi, 2009; 19(3):113-119.

20. Oktay İ, Kayışoğlu N. Tekirdağ İli 112 acil sağlı hizmetlerinin değerlendirilmesi. STED, 2005;14(2):35-37.

21. Önge T, Satar S, Kozacı N, ve ark. 112 ile acil tıp servisine getirilen erișkin hastaların analizi, Akademik Acil Tıp Dergisi. 2013, 12(3): 150-4.

22. Andjelik S. Accuracy of prehospital diagnosis of stroke. Cesk Slov Neurol. 2012; 75/108(1): 62- 68.

23. Smith WS, Isaacs M, Corry MD. Accuracy of paramedic identification of stroke and transient ischemic attack in the field. Prehosp Emerg Care. 1998 Jul-Sep;2(3):170-5.

24. Brandler ES, Sharma M, McCullough F, et al. Prehospital Stroke Identification: Factors Associated with Diagnostic Accuracy. J Stroke Cerebrovasc Dis. 2015 Sep;24(9):2161-6.

25. Wojner-Alexandrov AW, Alexandrov AV, Rodriguez D, et al. Houston paramedic and emergency stroke treatment and outcomes study (HoPST0). Stroke. 2005 Jul;36(7):1512-8.

26. Crocco TJ, Grotta JC, Jauch EC, et al. EMS Management of Acute Stroke-Prehospital Triage (Resource Document to Naemsp Position Statement). Prehosp Emerg Care. 2007 Jul-Sep;11(3):313-7.

27. You JS, Chung SP, Chung HS, et al. Predictive value of the cincinnati prehospital stroke scale for identifying trombolytic candidates in acute ischemic stroke. Am J Emerg Med. 2013 Dec;31(12):1699-702.

28. Katz BS, Mcmullan JT, Sucharew H, et al. Design and validation of a prehospital scale to predict stroke severity. Cincinnati prehospital stroke severity scale, Stroke. 2015 Jun;46(6):1508-12.

29. Kessler C, Khaw AV, Nabavi DG, et al. Standardized prehospital treatment of stroke. Dtsch Arztebl Int.2011;108(36): 585-91.

30. Zohrevandi B, Kasmaie VM, Asadi P, et al. Diagnostic accuracy of cincinnati prehospital stroke scale, Emerg (Tehran). 2015 Summer;3(3):95-8.

31. Wojner AW, Morgenstern L, Alexandrov AV, et al. Paramedic and Emergency Department Care of Stroke: Baseline Data From A Citywide Performance Improvement Study. American Journal of Critical Care, 2003;12( 5):411417.

32. Bray JE, Coughlan K, Barger B, et al. Paramedic diagnosis of stroke: examining long-term use of the Melbourne Ambulance Stroke Screen (MASS) in the field. Stroke. 2010 Jul;41(7):1363-6.

33. Fassbender K, Balucani C, Walter S, et al. Streamlining of prehospital stroke management: the golden hours, Lancet Neurol. 2013 Jun;12(6):585-96.

34. McPhee SJ, Hammur GD. Hastalıkların Fizyopatolojisi: Klinik Tıpla Bir Tanıșma. 6. Baskı, Palme Yayıncılık, Ankara, 2012.

35. Çakır Z, Bayramoğlu A, Aköz, A, ve ark. 112 acil yardım ambulansları ile getirilen hastalar için düzenlenen formların incelenmesi, Eurasian Journal Emergency Medicine. 2012; 11 (1): 23-26.

36. Röther J. Stroke - mimicking conditions. Magnetic Resonance Imaging in İschemic Stroke, 2006; 285

37. Zuckerberg D. Stroke mimics. Northern Westchester Hospital. 2015

38. Uzuner N, Kutluk K, Balkan S. İnme tanı ve tedavi kılavuzu. Türk Beyin Damar Hastalıkları Derneği, 2015 